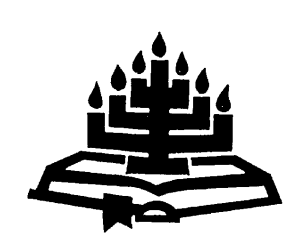

\title{
Die pastorale begeleiding van die aangenome kind met betrekking tot die Vaderskap van God
}

\author{
G.A. Lotter \& H.G. Hoepfner \\ Eenheid vir Reformatoriese Teologie \\ Potchefstroomkampus \\ Noordwes-Universiteit \\ POTCHEFSTROOM \\ E-pos: george.lotter@nwu.ac.za \\ hoefies@lantic.net
}

\begin{abstract}
Pastoral guidance of the adopted child with regard to the Fatherhood of God

In this article the significance of the Fatherhood of God for adopted children and the way they may be guided pastorally, is researched. The ongoing debate regarding adopted children and specific issues with them, like identity, rejection and loss, will be discussed. The father-image adopted children have of the biological and the adoptive father is respectively investigated, followed by a discussion of how the adopted child's image of God may be influenced by the image of an earthly father. Guidelines for the pastoral guidance regarding the Fatherhood of God and the forming of identity, as well as dealing with rejection and loss, are given. The article ends with some conclusions.
\end{abstract}

\section{Opsomming}

Pastorale begeleiding van die aangenome kind met betrekking tot die Vaderskap van God

In hierdie artikel word die betekenis van die Vaderskap van God by aangenome kinders ondersoek en ook hoe hulle pastoraal daarin begelei kan word. Die voortgaande debat oor aangenome kinders en spesifieke kwessies by aangenome kinders soos identiteit, verwerping en verlies word bespreek. Verder word die vaderbeeld wat aangenome kinders van onderskeidelik die biologiese vader en die aanneemvader het, ondersoek, gevolg deur ' $n$ bespreking van hoe die aangenome kind se beeld van 
God moontlik beïnvloed kan word deur die beeld van 'n aardse vader. Riglyne vir pastorale begeleiding tot 'n gesonde opvatting oor die Vaderskap van God en die vorming van identiteit, asook die hantering van verwerping en verlies, word gegee. Die artikel sluit af met enkele gevolgtrekkings.

\section{Inleiding}

Met die skryf van die artikel "Die doop van aangenome kinders" (Van der Walt, 1972:188 e.v.), is sommige van die belangrikste teologiese beginsels rakende aangenome kinders in vier bladsye neergepen, onder andere dat ons almal God se aangenome kinders is. Hierdie fokus het op een van die outeurs so 'n indruk gemaak dat daar dadelik op hierdie tema besluit is vir die artikel in die gedenkuitgawe ter ere van professor Tjaart van der Walt. Waarskynlik is die diepere emosionele motivering daarin geleë dat die Van der Waltegpaar ook twee aangenome kinders gehad het toe hy destyds die artikel geskryf het. (Een van die kinders is tragies oorlede en die ander een het haar met haar gesin en haar ouers in Australië gevestig.) Van der Walt (1974:188) maak self melding van hulle aangenome kinders aan die begin van die genoemde artikel. Daar is derhalwe geoordeel dat die ondersoek van nog 'n aangenome kind wat oor hierdie belangrike tema navorsing gedoen het (vgl. Hoepfner, 2009:viii), uiters relevant vir so ' $n$ bundel is.

Die doel van hierdie artikel is om aan te toon wat die betekenis van die Vaderskap van God by aangenome kinders is. Die volgende sake word in die artikel bespreek: die voortgaande debat oor aangenome kinders; kwessies wat aanneming raak soos identiteit, verwerping en verlies; die vaderbeeld by aangenome kinders en die invloed daarvan op die Godsbeeld. Na die bespreking van 'n verskeidenheid sake met betrekking tot aangenome kinders, word ten slotte riglyne voorsien vir die pastorale begeleiding van aangenome kinders, veral vir die belangrike dimensies wat deur die navorsing uitgewys is soos identiteit, verwerping en verlies.

\section{Die Vaderskap van God by aangenome kinders}

By die ondersoek oor die betekenis van die Vaderskap van God by aangenome kinders, is 'n uitgebreide bibliografiese soektog met behulp van die Ferdinand Postma Biblioteek aan die Noordwes-Universiteit gedoen deur Ferdikat, EbscoHost, Sabinet, Nexus en proefskrifte en verhandelings as databasisse te gebruik. Die resultaat van hierdie soektog het aangedui dat daar klaarblyklik, met die uitsondering van Passmore (2004), nog geen navorsing gedoen is oor die 
betekenis van die Vaderskap van God vir aangenome kinders nie. Alhoewel die begrip Die Vaderskap van God die afgelope aantal jare baie belangstelling uitgelok het, is dit duidelik dat daar ' $n$ leemte aan literatuur is wat oor God se Vaderskap en die pastoraat handel. Opvallend is dat iemand soos Jay Adams (1979:59), wat sy beradingsmodel op die Skrif grond, slegs verwys na die noodsaaklikheid daarvan dat die naam "Vader" in die pastoraat ten volle ontwikkel moet word, sonder dat hy dit self doen. In ander standaardwerke oor die pastoraat word min of geen aandag aan hierdie onderwerp gegee nie (vgl. onder andere Crabb, 1987; Collins, 1988; Louw, 1999; Patton, 1993; MacArthur \& Mack, 1994; Gerkin, 1997; McMinn, 1996; Heitink, 1999).

Daar is twee leemtes op die gebied van die pastoraat geïdentifiseer:

- Daar is min literatuur beskikbaar waarin die betekenis van die Vaderskap van God verder uitgewerk word.

- Daar is 'n tekort aan literatuur wat pastorale beraders begelei in die berading van aangenome kinders.

\section{Die voortgaande debat oor aangenome kinders}

Die literatuur oor aanneming kan breedweg in twee groepe verdeel word (vgl. Baratte, 2005:36). Aan die een kant is navorsers wat geen merkwaardige verskil waarneem tussen aangenome en nieaangenome kinders met betrekking tot gedragsverskynsels nie (Peters, 1999; Brand \& Brinich, 1999). Aan die ander kant is daar egter navorsers wat meen dat daar wel 'n noemenswaardige verskil waar te neem is (Wierzbicki, 1993; Howe, 1997; Miller et al., 2000a; 2000b; Smith, 2001:495; Smith \& Brodzinsky, 2002:213). Met verwysing na die sogenaamde "adopted child syndrome" waarsku Janus (1997: 270) dat navorsing rakende aanneming met versigtigheid benader moet word, aangesien dit gekompliseer word deur metodologiese probleme en die vooroordele van navorsers. Smith (2001: 496; vgl. ook Brand \& Brinich, 1999:1227) wy 'n hele artikel aan die term adopted child syndrome en kom tot die gevolgtrekking dat daar geen wetenskaplike bewys van so 'n sindroom bestaan nie. Aangenome kinders is wel oorverteenwoordig in psigologiese terapie (Howe, 1997:401; Miller et al., 2000a:1459; 2000b:1510; Smith \& Brodzinsky, 2002:213) en wel om die volgende redes (Brand \& Brinich, 1999:1227; vgl. ook Peters, 1999:316 en Miller et al., 2000a:1471): 
- Sommige aanneemouers mag moontlik "op die uitkyk wees vir probleme" as gevolg van die stigma wat binne sekere kulture aan aanneming gekoppel word.

- Probleme wat aangenome kinders ervaar, kan 'n aanneemfamilie makliker uiteenskeur as wanneer dieselfde probleme in 'n familie ervaar word waarin daar nie aangenome kinders is nie. Sulke probleme kan as 'n bedreiging vir die identiteit van die gesin beskou word.

- Aangesien baie aanneemouers gereelde kontak met maatskaplike werkers voor en na die aanneming gehad het, verstaan hulle die potensiële voordele wat psigologiese terapie kan inhou.

- Sommige navorsing (Brand \& Brinich, 1999:1227) dui aan dat aanneemouers 'n groter inkomste verdien as nie-aanneemouers en gevolglik makliker terapie vir hulle kinders kan bekostig.

Die verskillende navorsingsbevindings ten opsigte van gedragskwessies by aangenome kinders word goed saamgevat deur Smith en Brodzinsky (2002:213): “... while the majority of adopted children are well-adjusted, adoptees as a group are at somewhat greater risk for maladjustment than their non-adopted peers".

Alhoewel genetiese oorerwing, natuurlike temperament en omgewingsinvloede 'n groot rol speel in die gedrag van alle kinders (vgl. Howe, 1997:402), is dit duidelik dat sekere kwessies wel op 'n besondere manier deur aangenome kinders beleef word. Al gee aanneming per se nie tot emosionele en gedragsprobleme aanleiding nie (Brand \& Brinich, 1999:1228), kan aanneming wel ekstra bagasie wees in die geestelike, godsdienstige en opvoedkundige ontwikkeling van die persoon (Baratte, 2005:40; vgl. Fraser, 2005:65). Die kwessies wat die meeste deur navorsers uitgelig en bespreek word, word vervolgens aan die orde gestel.

\section{Spesifieke kwessies by aangenome kinders}

Verskeie navorsers bespreek verskillende kwessies wat by die aangenome kind voorkom. Lourens (2002:16-22) bespreek 'n aantal kwessies onder die volgende hoofde: aanpassing, ervaar van skeiding en verlies, vertroue, gevoel van onsekerheid, gevoel van behoort, gedrags- en emosionele probleme, selfbeeld en waardigheid, om ander daarvan te vertel, verwerping, identiteitsvorming en binding/gehegtheid. Met die huidige stand van navorsing in die geheel in gedagte, is dit duidelik dat alle kwessies tot twee hoofkwessies gereduseer kan word, naamlik identiteit, en verwerping en verlies. 
Die ander kwessies, soos onder andere deur Lourens uitgewys, sal as deel van hierdie twee hoofkwessies bespreek word. Identiteit, asook verwerping en verlies word vervolgens beskryf en bespreek.

\subsection{Identiteit}

Die kwessie rakende aangenome kinders wat die meeste deur navorsers gehanteer word, is identiteit (vgl. Janus, 1997:271; Peters, 1999:308; Miller et al., 2000b:1509 praat van "adoptive identity"). Baratte (2005:35) is van mening dat aanneming vir die kind die begin is van 'n lewenslange soeke om 'n outentieke bewussyn van hom-/haarself te bereik. Krueger en Hanna (1997:201; vgl. ook Janus, 1997:271) wys daarop dat die soeke na hulle biologiese wortels dwarsdeur die geskiedenis as een van die tipiese karaktertrekke by aangenome kinders uitgewys is. Hulle is soekend in 'n poging om sin uit 'n geheimsinnige verlede te maak wat belaai is met angs, onduidelikheid en onsekerheid. Nydam (1999:65) reken hulle ervaar op die een of ander manier dat iets ontbreek - 'n besef wat hulle van outentisiteit ontsê. Hierdie gevoel is die besef dat hulle ten volle in die werklikheid is, maar asof dele van hulleself onbekend of in 'n geheimenis gehul is. Lourens (2002:19) beweer dat "[a]angenome kinders worstel soms met die kwessie van oorsprong". By aangenome kinders is soms die onbewustelike poging om 'n eksistensiële leemte, 'n groot gemis (Saltzman, 1998:17), 'n gaping in die siel (Fraser, 2005:69) te probeer vul. Die aangenome kind kan hierdie leemte probeer vul deur óf negatief teenoor ander, veral teenoor die aanneemouers, op te tree (uittarting, woede, aggressie, lae selfwaarde), óf deur die ongesonde strewe na oorprestering en perfeksionisme (akademies, sport, musiek, ens.) (Fraser, 2005:69-70). Dit is belangrik dat enige berader die aangenome kind se soeke na identiteit sal ondersteun en dit binne die raamwerk van eksistensiële ontwikkeling sal plaas. Krueger en Hanna (1997:201; vgl. ook Fraser, 2005:74) meen 'n aangenome kind kan deur 'n soektog - of dit nou slaag of nie - sy/haar bestaan en afkoms as 'n normale aspek van persoonlike groei behoorlik in konteks plaas.

Die gemiddelde ouderdom van aangenome kinders wat na hulle biologiese ouers soek, is 29 jaar (Janus, 1997:272). Alhoewel nie alle aangenome kinders na hulle biologiese ouers sal soek nie - die meeste soekers is vroulik (vgl. Krueger \& Hanna, 1997:197; Janus, 1997:272) - voel die meeste aangenome kinders dat kennis van hulle biologiese ouers hulle wel met identiteitsvorming kan help (vgl. Krueger \& Hanna, 1997:196-197 wat na die sielkundige, Erik Erikson verwys wie se ontwikkeling en identiteit beïnvloed is deurdat hy 
nie sy biologiese vader geken het nie). Kennis van die biologiese ouers mag ook help om aanneming in 'n positiewe lig te sien en kan allerhande fantasieë en dagdromery oor biologiese ouers tot 'n einde bring (vgl. Nydam, 1999:66-67). Russell Saltzman (1998:17) kom tot die volgende konklusie nadat hy sy biologiese agtergrond vasgestel het: "Now I know beyond question, I was not abandoned to adoption. I was rescued by it."

Hier moet ook opgemerk word dat skuldgevoelens, lojaliteit teenoor die aanneemouers (vgl. Janus, 1997:271) en 'n vrees vir 'n tweede verwerping (Saltzman, 1998:17) dikwels die aangenome kind daarvan weerhou om na sy biologiese ouers te soek. Janus (1997:271) maak ook die stelling dat dit dikwels 'n skuldgevoel is wat aangenome kinders daarvan weerhou om na hulle natuurlike ouers te soek terwyl hulle aanneemouers nog leef.

Smith en Brodzinsky (2002:221) wys daarop dat die verlies van die biologiese ouers aanleiding kan gee tot 'n lae selfwaarde.

In 'n resente artikel bespreek Passmore (2004:165-175), 'n dosent in Sielkunde aan die Universiteit van Southern Queensland, die verhouding tussen God die Vader en aangenome kinders, met spesifieke verwysing na die kwessies van identiteit en verlies. Die waarde van die artikel lê daarin dat Passmore (2004:165) vanuit die Sielkunde as hulpwetenskap hierdie twee kwessies, wat met "several unique dimensions" by aangenome kinders manifesteer, uitwys en direk in verband bring met die Vaderskap van God. Wat identiteit betref, wys Passmore (2004:166) op die volgende:

While the establishment of a satisfactory identity can be a difficult task for many adolescents, adoptees face unique issues or challenges that may make some adopted adolescents and adults more vulnerable to identity confusion and a lowered sense of self worth.

Spesifieke kwessies en uitdagings wat aangenome kinders ervaar, het te doen met 'n diskontinuïteit tussen hulle genealogiese erfenis en hulle opvoeding. Passmore (2004:166) stel dit soos volg: "Adoptees typically do not look like the other members of their families, nor do they share the same genetic or social histories." Daarom dat vrae soos "Waar kom ek vandaan?" en "Soos wie lyk ek?" nie maklik beantwoord word nie (vgl. ook Baratte, 2005:35). Sonder die ankerpunt van 'n persoonlike geskiedenis wat hulle aanneming voorafgaan, mag dit vir sommige aangenome kinders moeilik wees om hulleself 
te differensieer van hulle aanneemouers en 'n identiteit van hulle eie te ontwikkel (Passmore, 2004:166).

Wanneer 'n aangenome kind die ouers van 'n eie, biologiese kind word, kan dit 'n besondere emosionele ervaring wees waar gevoelens van identiteit en herkoms 'n groot rol speel. Dit kom treffend na vore in die volgende gedeelte uit die dagboek van 'n aangenome dogter (Calvert, 2006:313):

\section{October 1978}

My baby was due on 1st October and finally I give birth on the $22 n d$. The baby is bruised and battered from the forceps so is in special care. The porter wheels me down to see her. The nurse puts her in my arms. I gaze into her face and don't notice the bruising. For the very first time in my life I have a companion my very own flesh and blood and, amazingly, she looks like me!

Lourens (2002:18) wys daarop dat aangenome kinders kan dink dat hulle anders is as kinders wat by hulle biologiese ouers grootword. 'n Rede hiervoor is dat aanneemouers hulle kinders dikwels probeer troos en bemoedig deur daarop te wys dat hulle spesiaal is en uitgekies is. Hierdie manier van troos moet versigtig hanteer word, aangesien die kind kan voel dat hy "gekies" is net omdat hy vroeër weggegee is (vgl. ook Krueger \& Hanna, 1997:196). Beraders moet die verskille wat die aangenome kind waarneem, erken en openlik daaromtrent wees. Dit kan help om die proses van aanvaarding makliker te maak.

Die tienerfase is moontlik die fase waarin aangenome kinders die sterkste op die verskille tussen hulle en hulle aanneemouers fokus (vgl. Baratte, 2005:36). Hulle weet gewoonlik min van hulle biologiese ouers en wat hulle wel weet, is dikwels in kontras met wat hulle graag wou hê hulle biologiese ouers moes wees. Die term identiteitsdiffuusheid sluit gevoelens soos "fragmentasie", "vervreemding" en "erfgenaamloosheid" in. Dit kan daartoe lei dat tieners hulleself "of onttrek, of rebels en opstandig reageer of 'n sterk behoefte toon om 'weg te gaan en die wêreld te sien' in die hoop om hul identiteit te vind" (Lourens, 2002:23). Die selfbeeld en waardigheid van adolessente aangenome kinders kom onder druk as gevolg van die feit dat hulle weggegee is en die gevolglike gebrek aan inligting. Hulle kan hulleself blameer vir die feit dat hulle aangeneem is en voel dat hulle iets verkeerds gedoen het (Lourens, 2002:21). 
Selfs al is dit moeilik om afleidings te maak ten opsigte van die selfrespek van aangenome kinders as 'n groep, moet aanvaar word dat, terwyl ...

... searches and reunions may answer many of the questions surrounding the adopted person's pre-adoption identity, many adoptees still struggle with the missing pieces - the unknown and/or unmet birth relatives, information that is blocked or not forthcoming, and conflicting data that do not seem to fit other information the adoptee has already been given (Passmore, 2004:166-167).

Die soeke na identiteit kan by aangenome kinders lewenslank duur, tensy daar 'n oplossing aangebied word wat nie deur genoemde faktore beïnvloed word nie.

\subsection{Verwerping en verlies}

Ten nouste verbind aan die kwessie van identiteit, is die kwessies van verwerping en verlies. Aangenome kinders ervaar verwerping en daarmee saam, verlies (vgl. Janus, 1997:270; Peters, 1999:308; Miller et al., 2000b:1509; Smith, 2001:214). Smith en Brodzinsky (2002:213) wys daarop dat aanneming inherent geassosieer word met verskeie verliesverwante ervarings, soos die verlies aan biologiese ouers en 'n uitgebreide biologiese familie. Fraser (2005:69) is selfs daarvan oortuig dat verlies die primêre kwessie rakende aanneming is waaruit al die ander kwessies voortvloei, terwyl Janus (1997:267) daarop wys dat gevoelens van verlies een van die hoofredes is waarom aangenome kinders berading soek.

Ten spyte van Janus (1997:270) se opmerking dat die meeste outeurs erken dat aangenome kinders verlies ervaar, meen Passmore (2004:167) dat die ervaring van verlies dikwels deur navorsing onderskat of selfs misken word.

Navorsing toon dat die kwessie van verwerping teruggevoer kan word na die prenatale fase. Die worsteling van die biologiese ma of sy haar kindjie moet opgee vir aanneming of nie, kan reeds die eerste ervaring van verwerping wees (Lourens, 2002:22). Die primêre verlies in aanneming het te doen met

not having been kept by one's original parents ... bonding doesn't begin at birth, but is a continuum of physiological, psychological and spiritual events which begin in utero and continue throughout the postnatal period (Passmore, 2004:167). 
Wanneer hierdie proses onderbreek word deur die skeiding van die kind en sy biologiese ma, word die ervaring van verwerping en verlies onuitwisbaar op die onderbewuste van die kind ingeprent. Dit lei tot die sogenaamde "primal wound" (Passmore, 2004:167; vgl. ook Verrier, 1993; Lourens, 2002:19; Fraser, 2005:65) en die ervaring van 'n "primal pain" (Baratte, 2005:35).

Tussen die ouderdom van drie tot sewe jaar word aangenome kinders bewus van hulle andersheid (Lourens, 2002:18), maar die latente stadium (sewe tot elf jaar) word as 'n kritiese periode beskou waarin die aangenome kind intellektueel en emosioneel ten volle bewus raak van wat dit beteken om aangeneem te wees (Baratte, 2005:36). Die kind begin verstaan dat sy aanneming die gevolg is van 'n biologiese ma wat hom weggegee het.

Die motief waarom die biologiese ma die kind vir aanneming opgee, speel geen wesenlik rol wanneer dit kom by die ervaring van verwerping nie. Selfs al word die kind vir aanneming opgegee as gevolg van goeie redes (bv. om 'n beter toekoms aan die kind te voorsien), voel die aangenome kind steeds die verwerping aan. In die woorde van 'n aangenome kind: "... being wanted by my adoptive parents doesn't compare to being unwanted by my birthmother" (Passmore, 2004:167). Die navorsing van Leon verskil van bogenoemde en wys daarop dat die vroegste ervarings van verlies by die aangenome kind te make het met sy aanneemma (vgl. Passmore, 2004:167). Wanneer die kind besef dat sy aanneemma hom nie "gedra" het nie, mag hy die gevoel van 'n fisiese verbintenis mis. Die gevoel van verlies groei met ander woorde uit die verbondenheid wat tussen die aanneemma en die aangenome kind ontwikkel het en nie uit teenwoordige gevoelens van verlies aan die biologiese ouers nie. Passmore (2004:167-168) se eie navorsing dui aan dat albei bogenoemde "verlies"-scenario's lewensvatbaar is. In plaas daarvan om te debatteer watter "verlies"-scenario meer betekenisvol is, moet albei eerder as oorsake van 'n gevoel van verwerping en verlies by aangenome kinders verstaan word.

Kwessies van vertroue en verraad word dikwels met verlies in verband gebring. Waar dit vir biologiese kinders 'n eerste sosiale prestasie is om hulle ma uit sig te verloor sonder om angstig te raak, is die primêre vertrouensverhouding by aangenome kinders reeds verbreek. By sommige aangenome kinders manifesteer 'n gevolglike wantroue in intieme verhoudings, aangesien hulle vrees dat die verhoudings in elk geval nie sal slaag nie. Vrees vir verwerping kan ook daartoe aanleiding gee dat die aangenome kind hom van verhou- 
dings onttrek of verhoudings kan uittoets en tot op 'n punt forseer waar dit in elk geval skipbreuk ly (Passmore, 2004:168).

Een van die moeilikste take waarmee aangenome kinders te doen $\mathrm{kry}$, is om 'n effektiewe band met hulle aanneemouers te vorm. Dit is "'n uiters komplekse area en 'n groot oorsaak van ontwrigting" (Lourens, 2002:23). Vrees vir verwerping kan hierdie verhouding negatief beïnvloed. Alhoewel gesinne met aangenome kinders 'n weerspieëling van God se liefde kan wees (Andersen, 1993:38), kan vrees vir verwerping die prentjie ernstig versteur. Sommige aangenome kinders vrees dat hulle deur hulle aanneemouers verwerp kan word en selfs weer aan hulle biologiese ouers teruggegee kan word. Daarom probeer hulle deur oorprestasie verwerping vermy (Lourens, 2002:21-22). Aan die ander kant kan aangenome kinders hulle aanneemouers wegstoot in ' $n$ poging om laasgenoemde se liefde te toets.

Lourens (2002:17) onderskei twee fases van rou by aangenome kinders, naamlik vroeë rou (fase een) en akute rou (fase twee). Vroeë rou word gekenmerk deur "... skok en afgestompheid, alarm en ontkenning". Akute rou word gekenmerk deur "verlange en hunkering, soeke en onderhandeling, sterk gevoelens soos woede, aggressie en skaamte, wanhoop en herorganisering". Dit is belangrik dat die kind die geleentheid sal kry om oor die verlede te rou, anders kan ander onopgeloste kwessies ontstaan.

\section{Die vaderbeeld by aangenome kinders}

\subsection{Die biologiese vader}

Die rol wat die biologiese vader by die aangenome kind speel, is klaarblyklik minder belangrik as die rol van die moeder, aangesien daar eerder na die biologiese ma as na die biologiese pa gesoek word (Nydam, 1997:66; Saltzman, 1998:16). 'n Moontlike rede hiervoor is die negatiewe beeld wat van die biologiese vader geteken word. Baumann (1999:375) wys daarop dat veral maatskaplike werkers hulle hieraan skuldig maak en biologiese pa's beskryf as verkragters, gevoelloos en mense wat nie omgee nie. Beraders sal bedag moet wees op die beeld wat die aangenome kind van sy biologiese vader het. Die vaderfiguur speel, bewustelik of onbewustelik, ' $n$ groot rol in die lewe van enige kind. Die belangrikheid van die vaderfiguur in die identiteitsontwikkeling van die kind kan nie genoeg beklemtoon word nie: "Children attach to emotionally available fathers, just as they do to mothers." (vgl. Kraft in Baumann, 1999:377.) Baumann (1999:380-389) se eie navorsing toon dat biologiese va- 
ders oor die algemeen nie selfsugtig en onverantwoordelik is nie, maar gretig en aktief deelneem aan die aanneemproses. Die beeld wat die aangenome kind van sy biologiese vader het, is waarskynlik presies die teenoorgestelde.

\subsection{Die aanneemvader}

Die rol van die vader in die lewe van enige kind, kan nie genoeg beklemtoon word nie. Williams (2004:22) beskryf hierdie rol soos volg:

The father helps the child establish an internal structure and psychological identity, thus lacking a father is equated to lacking a backbone ... Paternal absence results in children experiencing confusion about their sexual identity, unsteady selfesteem, repressed aggressivity and need for self-affirmation ...

Floyd en Morman (2003:609) het 'n insiggewende studie gedoen ten opsigte van die verhouding tussen aanneemvaders en hulle aangenome kinders. Deur die doel van ouers om 'n nageslag te verwek (die sogenaamde "procreation goal") in 'n navorsingstudie te betrek, het hulle bevind dat vaders geneig is om minder liefhebbend teenoor nie-biologiese seuns as teenoor biologiese seuns op te tree. Die rede hiervoor moet gesoek word in die onvermoë van aangenome kinders om die aanneemvader se gene na 'n volgende geslag oor te dra.

Vaders speel 'n sentrale en belangrike rol in die ontwikkeling van die kind se identiteit en aanpassing. Tamis-LeMonda (2004:221) haal Paquette soos volg aan:

... physical father-child play may have positive effects on the adaptation of children to their environment, rather than considering it to be simply a distraction with no developmental consequences that puts children at risk for injury.

Volgens Paquette kweek vaders 'n openheid tot die wêreld by hulle kinders deur interaktiewe optrede soos "non-object related play" (Tamis-LeMonda 2004:220; vgl. ook Williams, 2004:22-24). Daardeur stel vaders hulle kinders in staat om in die wêreld op te staan vir dít waarin hulle glo en om in onbekende situasies staande te bly. 


\subsection{Die aangenome kind se beeld van God kan beïnvloed word deur die beeld van sy aardse vader}

Die vader as gesinshoof en geestelike leier is in die besonder verantwoordelik vir die oordrag van Bybelkennis en die vaslê van Christelike waardes. Human (1992:220) vat dit soos volg saam:

Die kind moet geleer word dat God ' $n$ Vader is wat hom liefhet, wat vir hom sorg en wat 'n duidelike plan met sy lewe het - en wie is beter as die kind se vader om hom dit te leer?

'n Ongunstige vaderbeeld kan egter die kind se beeld van God as Vader negatief beïnvloed. Die ervaring wat die kind met sy eie vader het, kan na God geprojekteer word. "Indien sy eie vader hom verkleineer of verstoot, het hy geen grond om te glo dat God hom nie ook sal verwerp nie." (Reinhardt, 1990:36.) Alhoewel hierdie standpunt van Reinhardt vanuit 'n teologies-pastorale hoek aanvegbaar is, veral omdat sy meen dat daar uit die kind se oogpunt "geen grond" is om te glo dat God nie ook die kind sal verwerp nie (vgl. Powlison, 2003:172), moet saamgestem word dat die optrede van die vader die kind se Godsidee kan beïnvloed (Williams, 2004:26). Kinders wat 'n ongunstige beeld van hulle vader het, hetsy die biologiese vader of die aanneemvader, het dikwels ook 'n ongunstige beeld van God as Vader. Die uitdaging van die berader sal wees om aan die kind te wys dat daar wel grond is om positief oor God as Vader te dink, selfs al is sy verhouding met sy aardse vader nie na wense nie (vgl. Powlison, 2003:171-181).

Beraders sal hulleself in die begeleiding van aangenome kinders moet vergewis wat die beeld is wat laasgenoemde het van sowel hulle biologiese vader as hulle aanneemvader. Hierdie beelde kan hulle verstaan van God as Vader beïnvloed. In die artikel word verder aangetoon dat aangenome kinders, ten spyte van 'n negatiewe beeld van hulle aardse vader, wel 'n positiewe beeld van God as Vader kan ontwikkel (vgl. Hoepfner, 2009:146).

\section{Enkele pastorale riglyne in die begeleiding van die aangenome kind}

\subsection{Die Vaderskap van God en die vorming van identiteit}

Soos reeds aangetoon, speel die soeke na identiteit by aangenome kinders 'n groot rol. Dit is 'n soektog wat lewenslank kan duur indien geen oplossing aangebied kan word nie. Die gevoel van 'n eksistensiële leemte, 'n leë gevoel, kom algemeen voor. Aangenome kinders 
wil weet wie hulle is. Hulle hou gewoonlik vas aan die idee dat inligting oor hulle biologiese ouers kan help met die vorming van hulle identiteit (Hoepfner, 2009:66).

Die berader moet die beradene se soeke na identiteit ondersteun en binne die raamwerk van sy eksistensiële ontwikkeling plaas. Ondersteuning van hierdie soeke behels dat die berader die beradene op die betekenis van God se Vaderskap in die vorming van identiteit sal wys. Daar moet op die volgende sake gelet word:

- Gee hoop deur daarop te wys dat die Vaderskap van God sekerheid en standvastigheid kan gee in tye van identiteitsworsteling. Aan die hand van 1 Kronieke 17:13, 22:10 en 28:6 kan hierdie aspek verder verduidelik word.

- Brei daarop uit deur te verduidelik dat die gelowige reeds 'n kind van God die Vader is (vgl. Gal. 4:4-5). Baie aandag moet hieraan geskenk word, aangesien die regte verstaan van kindskap, 'n sleutelrol speel in die bepaling van 'n bybelse identiteit. Die volgende sake moet aan die orde kom:

- Die gelowige is kind van God op grond van aanneming. Aan die beradene moet verduidelik word dat alle gelowiges in 'n sekere sin "aangenome kinders" is (Van der Walt, 1974:189). Hy moet aan homself in die eerste plek nie as die aangenome kind van aanneemouers dink nie, maar as die aangenome kind van God die Vader. Hy is wettig God se kind. Sy identiteit lê in die feit dat hy die Vader se kind is. Jeremia 31:9 kan hier met groot vrug gebruik word. In 'n tyd toe Israel gewonder het wie se kind hy is, het die antwoord van Godsweë duidelik gekom dat hy God se kind is. Die beradene moet besef dat God nie onsensitief en onbetrokke ten opsigte van sy soeke na identiteit staan nie, maar dat Hy betrokke raak en die beradene op sy kindskap wys.

- Die beradene moet ook verstaan dat om kind van die Vader te wees, 'n heerlike voorreg is. Hy/sy is dit op grond van God se genade. God het hom/haar, sonder verdienste, uitverkies om sy kind te wees. Die berader moet baie klem hierop lê, sodat die beradene gelei kan word om in te sien hoe bevoorreg hy/sy is. Die beradene moenie aan hom-/haarself dink as 'n ongewenste kind of as iemand wat deur sy/haar biologiese ouers bloot weggegee is nie, maar as God se kind en boonop erfgenaam van die ewige lewe (vgl. onder andere Gal. 4:7). 
- Die aangenome kind mag God Abba noem (Rom. 8:15). Die berader moet moeite doen om die Abba-begrip aan die beradene te verduidelik: soos Jesus Christus die Seun van die Vader is en Hom Abba noem, kan die gelowige God ook Abba noem (Moule, 2000:29). Hier moet op die feit gewys word dat God as Abba aangespreek is in tye van spanning en onsekerheid (soos Jesus Christus dit gedoen het in uiterste wroeging volgens Mark. 14:36). Die wete dat God Abba is, kan sekerheid in tye van onsekerheid gee (soos bedoel in die briewe aan die Romeine en Galasiërs; vgl. ook Hoepfner, 2009:60).

- Die rol van die Heilige Gees moet beklemtoon word. Dit is Hy wat die gelowige daarvan oortuig dat $\mathrm{Hy}$ kind van die Vader is en op grond van God die Vader se liefde in Jesus Christus, dit as 'n realiteit kan ervaar (Fee, 2005:42). Dit is ook die Heilige Gees wat die gelowige so ver bring om met oortuiging God as Abba aan te spreek (Gal. 4:6). Die Gees maak die gelowige dus nie slegs 'n kind van God nie, maar maak hom ook daarvan bewus dat hy God se kind is (vgl. Lotter, 2005:490). Die Heilige Gees werk binne die terrein van 'n direkte en persoonlike ontmoeting met die opgestane Christus (Green, 2004:62). Gebed speel hier 'n belangrike rol. Daarom moet die beradene aangemoedig word om vir die verligtende werk van die Heilige Gees te bid.

\subsection{Die Vaderskap van God en die hantering van verwerping en verlies}

Alhoewel dit hier onder 'n afsonderlike opskrif behandel word, moet in gedagte gehou word dat die kwessie van verwerping en verlies nie werklik van die kwessie van identiteit geskei kan word nie. Waar verwerping en verlies tot identiteitsprobleme lei, kan die riglyne wat in punt 6 genoem is, gevolg word. 'n Ander resultaat wat soms as gevolg van gevoelens van verwerping en verlies na vore tree, is 'n wantroue in verhoudings (Hoepfner, 2009:70). Vanuit die Vaderskap van God kan dit op die volgende maniere hanteer word:

- Die verbondsgedagte moet hier sterk beklemtoon word.

- Die volgende sake kan uitgelig word:

- God die Vader wil graag met sy kinders in 'n verhouding staan. Hier kan klem op God se omgee en sorg gelê word en ook op die feit dat Hy as Vader in die behoeftes van sy kinders voorsien (Hoepfner, 2009:46). Daar moet ook op die belangrike 
saak klem gelê word dat Hy gedurig sy kinders na Hom terugroep (vgl. God se herhaalde oproepe tot bekering in die $\mathrm{Ou}$ Testament, veral Jer. 3). Wat die aangenome kind moet begryp, is dat God hom nooit sal verwerp of verlaat nie.

- Aansluitend hierby is die feit dat hierdie verhouding permanent van aard is. Die berader kan die feit beklemtoon dat die Vader ook die Skepper is wat nie die werke van sy hande laat vaar nie (Ps. 138:8; vgl. ook Fil. 1:6 en Joh. 10:28). Daar kan ook op die standvastigheid van God gewys word wat uitgedruk word deur die woordjie rots (Deut. 32:4).

- Die berader moet op die beradene se verantwoordelikheid ten opsigte van die verhouding tussen God en hom wys. God stel eise aan verbondskinders en roep hulle tot gehoorsaamheid en lofprysing op. Die verhouding tussen Hom en die gelowige kan net deur die gelowige verbreek word. Die verantwoordelikheid van die beradene om aan die verhouding te werk wat tussen God en hom bestaan, kan nie genoeg beklemtoon word nie, aangesien die beradene juis daartoe geneig is om verhoudings uit te toets. Die manier om aan die beradene se verhouding met God te werk, is om hom/haar tot 'n gehoorsame lewe en lofprysing op te roep. Laasgenoemde kan veral sinvol in die aanbiddingsgeleenthede van die plaaslike gemeente plaasvind waar hy/sy bewustelik die lof van God saam met sy/haar "aangenome" broers en susters besing.

Die gekruisigde Christus dien as die oriënteringspunt in die verlede vanwaar die aangenome kind sinvol oor die kwessies van identiteit, verwerping en verlies kan besin. Dit is immers deur geloof in Jesus Christus en die toepassende werk van die Heilige Gees dat die wete daar is dat hy/sy as kind van God die Vader aangeneem is. Sy/Haar identiteit lê daarin dat hy/sy God die Vader se kind is. God verwerp nooit sy kinders nie. Wanneer die beradene vra "Wie is ek?", kan dit met 'n duidelike "Ek is 'n kind van God die Vader" beantwoord word. Indien die Heilige Gees die aangenome kind van laasgenoemde waarheid oortuig, behoort die leë gevoel, die gevoel dat iets ontbreek, te verdwyn.

\section{Gevolgtrekkings}

In hierdie artikel is die betekenis rakende die Vaderskap van God by aangenome kinders ondersoek. Daar is aangetoon dat daar 'n voortgaande debat is oor aangenome kinders en spesifieke kwessies soos identiteit, verwerping en verlies word bespreek. Die vaderbeeld 
by aangenome kinders ten opsigte van onderskeidelik die biologiese vader en die aanneemvader, is ondersoek en gevolg deur 'n bespreking van hoe die aangenome kind se Godsbeeld moontlik deur die beeld van ' $n$ aardse vader beïnvloed kan word. Ten slotte word riglyne gegee vir die pastorale begeleiding oor die Vaderskap van God en die vorming van identiteit, asook die hantering van verwerping en verlies.

\section{Geraadpleegde bronne}

ADAMS, J.E. 1979. A theology of Christian counseling: more than redemption. Grand Rapids: Zondervan.

ANDERSEN, D.V. 1993. When God adopts. Christianity today, 19:36-39.

BARATTE, L.L. 2005. Growing within our hearts: explorations in the faith development and pastoral care of adopted children and their parents. Journal of family ministry, 19(4):32-43.

BAUMANN, C. 1999. Adoptive fathers and birthfathers: a study of attitudes. Child and adolescent social work journal, 16(5):373-391.

BRAND, A.E. \& BRINICH, P.M. 1999. Behavior problems and mental health contacts in adopted, foster, and nonadopted children. Journal of child psychology and psychiatry, 40(8):1221-1229.

CALVERT, B. 2006. Theological reflections of an adopted daughter. Theology \& sexuality, 12(3):309-318.

COLLINS, G.R. 1988. Christian counseling: a comprehensive guide. Nashville: W. Publishing Group.

CRABB, L. 1987. Understanding people: why we long for relationship. Grand Rapids: Zondervan.

FEE, G.D. 2005. Paul, the Spirit, and the people of God. Peabody: Hendrickson.

FLOYD, K. \& MORMAN, M.T. 2003. Human affection exchange. Part. 2: Affectionate communication in father-son relationships. The journal of social psychology, 143(5):599-612.

FRASER, R.N. 2005. A fairy tale with a twist: pastoral counseling with adoptive families. Journal of pastoral care \& counseling, 59(1 \& 2):63-78.

GERKIN, C.V. 1997. An introduction to pastoral care. Nashville: Abingdon.

GREEN, M. 2004. I believe in the Holy Spirit. Grand Rapids: Eerdmans.

HEITINK, G. 1999. Practical theology: history, theory, action domains - manual for practical theology. Kampen: Kok.

HOEPFNER, H.G. 2009. Die betekenis van die Vaderskap van God in die pastorale begeleiding van aangenome kinders. Potchefstroom: NWU. (Ph.D.proefskrif.)

HOWE, D. 1997. Parent-reported problems in 211 adopted children: some risk and protective factors. Journal of child psychology and psychiatry, 38(4):401-411.

HUMAN, M. 1992. Die invloed van vaderafwesigheid op die kind. Johannesburg: RAU. (M.Ed.-skripsie.)

JANUS, N.G. 1997. Adoption counseling as a professional specialty area for counselors. Journal of counseling \& development, 75:266-274. 
KRUEGER, M.J.J. \& HANNA, F.J. 1997. Why adoptees search: an existential treatment perspective. Journal of counseling and development, 75:195202.

LOTTER, G.A. 2005. Die werk van die Heilige Gees volgens 2 Korintiërs en moontlike pastorale implikasies daarvan. In die Skriflig, 39(3):487-504.

LOURENS, J.A.E. 2002. Die toepassing van gesinsterapie in gesinne met aangenome kinders. Pretoria: UNISA. (M.Ed.-verhandeling.)

LOUW. D.J. 1999. Pastoraat as vertolking en ontmoeting: teologiese ontwerp vir 'n basisteorie, antropologie, metode en terapie. Wellington: Lux Verbi.BM.

MacARTHUR, J.F. \& MACK, W.A. 1994. Introduction to biblical counseling: a basic guide to the principles and practice of counseling. Nashville: W Publishing Group.

McMINN, M.R. 1996. Psychology, theology and spirituality in Christian counseling. Wheaton: Tyndale House.

MILLER, B.C., FAN, X., CHRISTENSEN, M., GROTEVANT, H.D. \& VAN DULMEN, M. 2000a. Comparison of adopted and nonadopted adolescents in a large, nationally representative sample. Child development, 71(5):1458-1473.

MILLER, B.C., FAN, X., CHRISTENSEN, M., GROTEVANT, H.D. \& VAN DULMEN, M. 2000b. Adopted adolescents' overrepresentation in mental health counseling: adoptees' problems or parents' lower threshold for referral? Journal of the American Academy of Child \& Adolescent Psychiatry, 39(12):1504-1511.

MOULE, C.F.D. 2000. The Holy Spirit. London: Continuum.

NYDAM, R.J. 1997. Adoptees come of age: living within two families. Louisville: Westminster John Knox.

PASSMORE, N.L. 2004. Adoption and the Father heart of God: helping adoptees deal with issues of identity and loss. Journal of psychology and Christianity, 232(2):165-175.

PATTON, J. 1993. Pastoral care in context: an introduction tot pastoral care. Louisville: Westminster/John Knox.

PETERS, B.R. 1999. Adopted children's behavior problems: a review of five explanatory models. Clinical psychology review, 19(3):297-328.

POWLISON, D. 2003. Seeing with new eyes. Phillipsburg: P \& R.

REINHARDT, S. 1990. Die invloed van die vaderbeeld op die adolessent se verhoudingsprobleme. Pretoria: UP. (M.Ed.-skripsie.)

SALTZMAN, R.E. 1998. A fear of abandonment. First things, 80:16-18.

SMITH, D.W. \& BRODZINSKY, D.M. 2002. Coping with birthparent loss in adopted children. Journal of child psychology and psychiatry, 43(2):213223.

SMITH, J. 2001. The adopted child syndrome: a methodological perspective. Families in society: the journal of contempory human services, 82(5):491497).

TAMIS-LEMONDA, C.S. 2004. Conceptualizing fathers' roles: playmates and more. Human development, 47(4):220-227.

VAN DER WALT, T. 1972. Die doop van aangenome kinders. (In Almanak van die Gereformeerde Kerke in Suid-Afrika, Jg. 96. Potchefstroom: Administratiewe Buro.)

VERRIER, N. 1993. The primal wound: understanding the adopted child. Baltimore: Gateway. 
WIERZBICKI, M. 1993. Psychological adjustment of adoptees: Ameta-analysis. Journal of clinical child psychology, 22(4):447-454.

WILLIAMS, C.M. 2004. An exploration of father-child relationships, current attachment styles and self-esteem amongst adults. Port Elizabeth: NMMU. (M.A.Psych. dissertation.) [CD.]

\section{Kernbegrippe:}

aangenome kind

pastorale begeleiding

Vaderskap van God

Key concepts:

adopted child

Fatherhood of God

pastoral guidance 